\title{
ПРАВОВОЙ СТАТУС ГОРОДСКИХ ЛЕСОВ В РОССИИ (КОНЕЦ XIX - НАЧАЛО ХХ ВЕКА)
}

\begin{abstract}
Аннотация: В статье Пуряевой А.Ю. рассматривается правовой режим лесов, расположенных на территориях городов (городских лесов) России в коние ХІХ - начале ХХ века. Приводятся нормы Лесных уставов разных редакиий, действовавиих в России до 1917 года, а также первые акты советской власти, отражавшие правовой статус городских лесов. Автор подчеркивает, что в дореволюиионный период, города могли владеть лесами, как на праве собственности, так и посредством закрепления не на праве собственности. А особенностью правового статуса городских лесов в первые годы советской власти является отнесение городских лесов к единому государственному лесному фонду.
\end{abstract}

Ключевые слова: Юриспруденция, лес, лесное, законодательство, России, городские, леса, лесной, фонд, история

B

последнее время в науке активно обсуждается правовой статус городских лесов в рамках действующего лесного законодательства в связи с принятием Лесного кодекса Российской Федерации 2006 года ${ }^{1}$. В соответствии с ч.1 статьи 6 Лесного кодекса РФ 2006 года леса располагаются на землях лесного фонда и землях иных категорий. То есть, в том числе на землях населенных пунктов, в рамках деления земель РФ на категории, предусмотренном земельным законодательством. В соответствии с ч.2 ст.8 Лесного кодекса РФ 2006 года формы собственности на лесные участки в составе земель иных категорий (то есть не земель лесного фонда) определяются в соответствии с земельным законодательством. Данная норма фактически не нашла своего дальнейшего развития, позволяющего однозначно толковать форму собственности на лесные участки в составе земель населенных пунктов, не говоря уже о самих городских лесах, понятие которых не тождественно понятию лесных участков в составе земель населенных пунктов. Отмечается, что собственность на городские леса является не федеральной, $\mathrm{a}$ «неразграниченной государственной собственностью» ${ }^{2}$, и лесное законодательство «не содержит положений, позволяющих определить форму собственности на земли, занятые городскими лесами, и на лесные участки, из них образованные» ${ }^{3}$. Поскольку норма ст.84 Лесного кодекса РФ 2006 года ставит зависимость владения, пользования и распоряжения лесными участками органами местного самоуправления от титула муниципальной собственности на них, данный вопрос имеет несомненную актуальность.

1 Лесной кодекс Российской Федерации №200-Ф3 от 04 декабря 2006 г. // Российская газета. - 08 декабря 2006.

${ }^{2}$ Кичигин Н.В. Городские леса: режим // Журнал российского права. - 2011. - №6.

${ }^{3}$ Нарышева Н.Г. Право собственности на земли, занятые городскими лесами // Имущественные отношения в Российской Федерации. - 2010. - №12.
На наш взгляд целесообразно осветить вопрос о правовом статусе городских лесов в историческом аспекте в период, предусматривающий многообразие форм собственности на леса в нашей стране, достигший достаточно высокого уровня развития правовых актов лесного права в конце XIX века, а также в переходный период - начала XX века.

В 1857 году Н. Шелгуновым приведена следующая классификация лесов по владению:

Леса казенные

Леса корабельные

Леса приписанные к разным промыслам, фабрикам и заводам. Они подразделялись на: леса горных заводов; леса винокуренных заводов; леса соляных заводов; леса казенных конных заводов; леса тульских оружейных заводов; леса военных поселений.

Леса духовного ведомства.

Леса городские.

Леса колонистов

Леса удельного ведомства.

Леса частные

Леса арендные и старостинские.

Леса поиезуитские и ленные.

Леса казенных крестьян.

Наконец леса общие, въезжие и спорные ${ }^{4}$.

Эта классификация лесов соответствовала тексту Лесного устава 1842 года издания, 1857 года издания, а также последующих редакций за некоторыми исключениями 5 .

${ }^{4}$ Шелгунов Н. История русского лесного законодательства. - СанктПетербург. Типография Министерства гос. им-в, 1857. - С. 347-360.

5 Устав лесной 1842 года издания // СЗРИ. - Свод уставов казенного управления. - Т. 8. - Ч. 4. - Уставы лесной, о казенных оброчных статьях, о хозяйственном управлении казенных населенных имений. - СПб., 1842; Устав лесной 1857 года издания // СЗРИ. - Т.8 - Ч.І. - СПб.,1857; Устав лесной 1876 года издания // СЗРИ. - Т.8 - Ч.І - Уставы: лесной, о казенных оброчных статьях, об управлении казенными имениями в Западных и Прибалтийских губерниях. - СПб., 1876. 


\section{Право и политика 5 (161) 2013}

Согласно Уставу лесному 1905 года леса разделялись на:

- государственные;

- состоящие в общественной собственности;

- состоящие в частной собственности.

Леса ведомства Кабинета Его Императорского Величества в Алтайском и Нерчинском округах составляли собственность Государя Императора и управлялись на основании особых правил.

Государственные леса - это те леса, которые составляли собственность казны. Государственные леса разделялись на: казенные и на имеющие особое предназначение.

Казенными назывались те государственные леса, которые не были отведены к особым ведомствам, не были приписаны к каким либо установлениям, заведениям или обществам, и состояли в непосредственном распоряжении казны.

Государственные леса, имеющие особое предназначение - это были те леса, которыми предоставлено пользоваться особым ведомствам, установлениям, заведениям или обществам.

К лесам, имеющим особое предназначение принадлежали следующие леса:

«1) назначенные для различных военных устройств, как то; крепостей и проч.

2) приписанные к разным казенным и частным заводам, как то: к горным, соляным, винокуренным, оружейным, пороховым и проч., а также разным фабрикам и промыслам.

3) государственные леса, из коих довольствуются лесом селения бывших государственных крестьян, до производства им лесных наделов, а также леса, отведенные в надел крестьянам и инородцам в Сибири и государственным поселянам в Закавказье.

4) принадлежащие к казенным имениям заказных и Прибалтийских губерний.

5) отведенные городам, в коих введено городовой Положение.

6) предоставленные в наделение колонистам.

7) выделенные монастырям.

8) состоящие в пользовании инородцев, казачьих войск и т.п.» ${ }^{6}$.

Те леса, которые не принадлежали к государственным лесам - находились на праве собственности: обществ или частных лиц, «именуемые общественными или частными» ${ }^{7}$.

К общественным лесам принадлежали:

«1) леса, приобретенные духовным ведомством, архиерейскими домами, монастырями, церквами, пасторатами, посредством покупки, дара или завещания разных лиц.

${ }^{6}$ Ст.6. Устав лесной 1905 г. // СЗРИ. - Т. 8. - Ч.1. - СПб., 1905 г.

${ }^{7}$ Ст.7. Там же.
2) леса, приобретенные в собственность по грамотам или покупкою разными обществами, учеными сословиями, богоугодными заведениями, учреждениями, именуемыми у магометан вакуфами и проч.

3) леса, приобретенные в собственность: а) городами и б)обществами сельских обывателей.

4) леса, предоставленные в надел селениям бывших государственных крестьян по владенным записям и

5) леса казачьих войск» ${ }^{8}$.

К частным относились леса:

«1) удельнаго ведомства.

2) Особ Императорской фамилии.

3) состоящих в частном владении поиезуитских и ленных имений.

4) дворян, состоящие в их владении на основании общих узаконений или майоратские и т.п.

5) лиц прочих состояний»9.

Устав лесной 1913 года ${ }^{10}$ деление лесов по формам собственности не менял. Ю.И. Шуплецова приходит к верному выводу о том, что леса в тот период были разделены на две формы собственности: государственную и частную, «поскольку общественные леса, по своей сути, представляли собой собственность «юридических лиц»» ${ }^{11}$.

Как видим, городские леса составляли самостоятельную классификационную группу, выделявшуюся по принадлежности владения.

С 1801 года городские леса были предоставлены городским обществам, на основании городового положения ${ }^{12}$, т.е. тем, у которых в планах значились леса или леса находились в черте города. Остальные были под надзором лесного управления, но в 1832 году переданы городам снова и заведывание ими возложено было на Городские Думы ${ }^{13}$. Города признавались обществами и потому леса городов относились к общественным лесам ${ }^{14}$. По тексту Лесного устава 1842 года издания, леса, отведенные городам, выделялись в составе государственных лесов, имеющих особое

\footnotetext{
${ }^{8}$ Ст.8. Там.же.

${ }^{9}$ Ст.9. Устав лесной 1905 г. // СЗРИ. - Т. 8. - Ч.1. - СПб., 1905 г.

${ }^{10}$ Устав Лесной 1913 г. // СПб., 1913 (Типолитография Якорь).

${ }^{11}$ Шуплеиова Ю.И. Вещные права на природные ресурсы: публичные и частные интересы [Текст] / Ю.И. Шуплецова. - М.: ИД «Юриспруденция», 2007. - С.54.

${ }^{12}$ Манифест О восстановлении городового Положения и грамоты, данной городам 02 апреля 1801 г. // ПСЗРИ. - 1- е собр. - Т. XXVI. - 1800-1801. - С.602.

${ }^{13}$ Указ Сенатский О предоставлении казенных лесов в заведении селений, монастырей и городских обществ 10 ноября 1832 г. // ПСЗРИ. - 2-е собр. - Т. VII. - 1832. - С. 831-835.

${ }^{14}$ Ст.7 Свод Устава лесного 1835 года издания // СЗРИ. - Т. 8 Ч.4. - СПб., 1835.
} 
предназначение ${ }^{15}$. Леса, приобретенные городами посредством покупки или по смерти лиц, принадлежащих к их обществам, не оставивших после себя ни завещаний, ни законных наследников, относились к общественным лесам - леса, которые составляют собственность обществ. ${ }^{16}$ Таким образом, города могли владеть лесами, как на праве собственности, так и посредством закрепления не на праве собственности.

Устав лесной 1905 года относительно городских лесов закреплял то, что леса, растущие на выгонах, принадлежащих городам, где не введено в действие Городовое Положение, когда они имеют утвержденные планы и простираются не далее двух верст вокруг города, предоставлялись в полное распоряжение тех городов, исключая деревья годные на кораблестроение, которые оставались в ведении лесного начальства. Рубка на корне стоящих деревьев городского леса дозволялась только в случаях крайней необходимости с разрешения Губернатора.

Леса, приобретенные городами посредством покупки или по правилам об обращении в пользу городов выморочных имуществ, а также леса, растущие на выгонах, принадлежащих городам, где введено Городовое Положение, составляли собственность городов и управлялись на общих основаниях, установленных для управления городским имуществом ${ }^{17}$.

В соответствии с Уставом лесным 1913 года леса, приписанные, выделенные или предоставленные в постоянное, либо временное пользование особым ведомствам, установлениям, заведениям или обществам, как то: казенным или частным горным, соляным и иным промышленным и сельско-хозяйственным предприятиям, различным военным устройствам (крепостям, стрельбищам и т.п.), учебным заведениям, церквам и монастырям, пасторатам, некоторым разрядам сельских обывателей, городам, в которых не введено Городовое Положение, находились в хозяйственном управлении и заведывании тех ведомств и установлений, для потребности которых они были отведены. Но Правила сбережения и охранения этих лесов были в ведении Главного Управления Землеустройства и Земледелия, по Лесному Департаменту ${ }^{18}$.

${ }^{15}$ Ст. ст. 6, 7. Устав лесной 1842 года издания // СЗРИ. - Свод уставов казенного управления. - Т. 8. - Ч. 4. - Уставы лесной, о казенных оброчных статьях, о хозяйственном управлении казенных населенных имений. - СПб., 1842.

${ }^{16}$ Ст. 8, 9 Устав лесной 1842 года издания // СЗРИ. - Свод уставов казенного управления. - Т. 8. - Ч. 4. - Уставы лесной, о казенных оброчных статьях, о хозяйственном управлении казенных населенных имений. - СПб., 1842.

${ }_{17}^{17}$ С.сст. 465-466, 469. Устав лесной 1905 года издания // СЗРИ. Т. 8. - Ч.1. - СПб., 1905.

${ }^{18}$ Устав Лесной 1913 года издания // СПб., 1913 (Типолитография Якорь).
После свержения самодержавия и принятия Съездом советов рабочих и солдатских депутатов в 1917 году Декрета «О земле»19, а в 1918 года принятия Всероссийским Центральным исполнительным комитетом Декрета «О лесах» ${ }^{20}$, правовой статус городских лесов получил свое отражение в тексте Лесного кодекса РСФСР 1923 года, вступившего в силу с 1 августа 1923 года ${ }^{21}$. Согласно Лесному кодексу РСФСР 1923 года единый государственный лесной фонд 22 делил леса на: а) леса местного значения; б) леса общегосударственного значения.

Леса общегосударственного значения по роду пользования в соответствии с Лесным кодексом РСФСР 1923 года делились на:

а) леса собственно государственные;

б) леса особого назначения.

К лесам особого назначения относились лесные дачи, выделяемые из лесов общегосударственного значения для удовлетворения особых нужд государства. К ним в частности относились:

а) защитные лесные дачи;

б) учебно-опытные лесные дачи и памятники природы;

г) горно-заводские леса;

г) городские;

д) эксплуатируемые на основе концессионных договоров;

е) предоставленные государственным транспортным или промышленным предприятиям и их объединениям в порядке создания комбинированных хозяйств. «Объединение столь различных по роли в народном хозяйстве лесов (с ограниченным пользованием и интенсивной эксплуатацией) в одну категорию лесов «особого назначения» имело своим единственным основанием то, что перечисленные леса подлежали передаче от органов земельных в управление других организаций, причем подобная передача должна была носить временный характер, так как по истечении срока пользования, а также по миновании надобности в этих лесах они подлежали возврату в общий эксплуатационный фонд - «леса собственно государственные» ${ }^{23}$.

\footnotetext{
${ }^{19}$ Декрет «О земле» от 26 октября (8 ноября) 1917 г. // СУ РСФСР. - 1917. - №1. - Ст.2.

${ }^{20}$ Декрет «О лесах» от 27 мая 1918 г. // СУ РСФСР. - 1918. - №42. - Ст.522.

21 Лесной кодекс РСФСР 1923 г. // Библиотека Советской деревни. - Ленинград: Рабочее Издательство «Прибой», 1924.

22 Понятие «единого государственного лесного фонда» в дореволюционном лесном законодательстве России отсутствовало.

${ }^{23}$ Полянская Г.Н. Право государственной собственности на леса в СССР. - М.: Государственное издательство юридической литературы, 1959. - С.225.
} 


\section{Право и политика 5 (161) • 2013}

Таким образом, городские леса входили в понятие единого государственного лесного фонда и относились к лесам особого назначения.

В целях правильного использования имеющихся пригородных лесов, а также садов, парков рощ в черте городских поселений, имеющих большое значение для здоровья населения, и в целях их дальнейшего развития было принято постановление Народных Комиссариатов Внутренних дел и Здравоохранения 03 мая $1920 \Gamma^{24}$. В соответствии с указанным постановлением коммунальным отделам совместно с представителями санитарных отделов надлежало:

- произвести учет всех имеющихся в городских поселениях и их пригородах и рабочих поселках зеленых насаждений, то есть садов, парков, скверов, пригородных рощ и лесов, причем учету подлежали участки от $1 / 2$ десятины. Учету подлежали все зеленые участки, как в пределах самого города, так и в окружной полосе, определяемой местными советами, как площадь для будущих распределений и строительства города;

- разработать план использования зеленой площади, кроме фруктовых садов;

- принять меры к дальнейшему расширению зеленых насаждений в городах и пригородах и рабочих поселках, выработать соответствующие планы новых посадок и особенно обеспечить этим окраины и другие районы, лишенные растительности;

- принять меры к тщательной охране всех существующих в городах, пригородах и поселках зеленых насаждений, воспретив всякую вырубку и уничтожение древесных насаждений без разрешения специальных органов надзора ${ }^{25}$.

В целях разграничения земель городов от иных земель была принята Инструкция о городских землях постановлением НКЗ и Внутренних Дел от 18 июля $1923 \Gamma^{26}$. Все земли внутри городской черты находились в административном и хозяйственном заведывании городского совета и подчиненных им коммунальных отделов. Постановления Земельного кодекса РСФСР на эти земли не распространялось. Городская черта согласно Инструкции охватывали все застроенные кварталы города с находящимися на них садами, парками, огородами, а также с непосредственно

${ }^{24}$ Постановление Народных Комиссариатов Внутренних Дел и Здравоохранения «Об охране зеленой площади (садов, пригородных лесов и других зеленых насаждений» от 03 мая 1920 г. // СУ РСФСР. - 1920. - №32. - Ст.157.

${ }^{25}$ П. 1-5. Постановление Народных Комиссариатов Внутренних Дел и Здравоохранения «Об охране зеленой площади (садов, пригородных лесов и других зеленых насаждений» от 03 мая 1920 г. // СУ РСФСР. - 1920. - №32. - Ст.157.

${ }^{26}$ Постановление Народного Комиссариата Земледелия и Внутренних Дел «Инструкция по применению постановления о городских землях» от 18 июля 1923 г. // СУ РСФСР. - 1923. - №77. - Ст.746. примыкающими к ним незастроенными землями: которые ранее были городскими или состояли в фактическом заведывании городских Советов к 1 августа $1922 \Gamma^{27}$. Для определения действующей городской черты и выяснения границ города принимались во внимание:

- сохранившиеся документы и планы дореволюционного времени;

- документы, планы, распоряжения, постановления, на основании которых можно установить какие земли находились в заведывании городских Советов к 1 августа 1922 г.;

- сведения и документы, полученные по особому запросу от местных земельных органов и волостных исполнительных комитетов, на основании которых можно было установить какие земли, примыкающие к городу, к 1 августа 1922 года не состояли в фактическом управлении волостных исполнительных комитетов или непосредственном ведении земельных органов НКЗ;

- опроса должностных лиц, ведавших городским земельным хозяйством до указанного выше срока, а также местных граждан, в фактическом пользовании которых находились земельные участки, граничащие с волостными землями.

Перемещение городской черты могло производиться в случае необходимости расширения города, в том числе в целях расширения зеленой зоны ${ }^{28}$.

В соответствии с Лесным кодексом РСФСР 1923 года заведывание лесами единого государственного лесного фонда было возложено на органы соответствующего Народного Комиссариата Земледелия.

Выводы: Понятие городского леса, лесного законодательство России в конце XIX - начале XX века не раскрывало. Место расположения городских лесов, как в дореволюционном лесном законодательстве, так и в лесном законодательстве первых годов советской власти зависело от вхождения их в черту города. Особенность правового режима городских лесов зачастую характеризовалась тем, что городские леса имели уникальные природоохранные функции, выполняли рекреационную нагрузку и имели экологическую значимость. В дореволюционный период, города могли владеть лесами, как на праве собственности, так и посредством закрепления не на праве собственности. А особенностью правового статуса городских лесов в первые годы советской власти является отнесение город-

${ }^{27}$ П.3-4. Постановление Народного Комиссариата Земледелия и Внутренних Дел «Инструкция по применению постановления о городских землях» от 18 июля 1923 г. // СУ РСФСР. - 1923. №77. - Ст.746.

${ }^{28}$ П.12, 21. Постановление Народного Комиссариата Земледелия и Внутренних Дел «Инструкция по применению постановления о городских землях» от 18 июля 1923 г. // СУ РСФСР. - 1923. №77. - Ст.746. 
ских лесов к единому государственному лесному фонду. Сбережение и охрана городских лесов в соответствии с лесным законодательством России в конце XIX - начале $\mathrm{XX}$ века были в ведении государственных органов.

\section{Библиография:}

1. Декрет «О земле» от 26 октября (8 ноября) 1917 г. // СУ РСФСР. - 1917. - №1. - СТ.2.

2. Декрет «О лесах» от 27 мая 1918 г. // СУ РСФСР. 1918. - №42. - Ст.522.

3. Кичигин Н.В. Городские леса: режим // Журнал российского права. - 2011. - №6.

4. Лесной кодекс РСФСР 1923 г. // Библиотека Советской деревни. - Ленинград: Рабочее Издательство «Прибой», 1924.

5. Лесной кодекс Российской Федерации №200-Ф3 от 04 декабря 2006 г. // Российская газета. - 08 декабря 2006.

6. Манифест О восстановлении городового Положения и грамоты, данной городам 02 апреля 1801 г. // ПСЗРИ. - 1- е собр. - T. XXVI. - 1800-1801. - С.602.

7. Нарышева Н.Г. Право собственности на земли, занятые городскими лесами // Имущественные отношения в Российской Федерации. - 2010. - №12.

8. Полянская Г.Н. Право государственной собственности на леса в СССР. - М.: Государственное издательство юридической литературы, 1959. - 407 с.

9. Постановление Народных Комиссариатов Внутренних Дел и Здравоохранения «Об охране зеленой площади (садов, пригородных лесов и других зеленых насаждений» от 03 мая 1920 г. // СУ РСФСР. - 1920. - №32. - Ст.157.

10. Постановление Народного Комиссариата Земледелия и Внутренних Дел «Инструкция по применению постановления о городских землях» от 18 июля 1923 г. // СУ РСФСР. - 1923. - №77. - СТ.746.

11. Указ Сенатский О предоставлении казенных лесов в заведении селений, монастырей и городских обществ 10 ноября 1832 г. // ПСЗРИ. - 2-е собр. - T. VII. - 1832. - C. 831-835.
12. Свод Устава лесного 1835 года издания // СЗРИ. Т. 8 - Ч.4. - СПб., 1835.

13. Устав лесной 1842 года издания // СЗРИ. - Свод уставов казенного управления. - Т. 8. - Ч. 4. - Уставы лесной, о казенных оброчных статьях, о хозяйственном управлении казенных населенных имений. - СПб., 1842 ;

14. Устав лесной 1857 года издания // СЗРИ. - Т.8 - Ч.І. - СПб.,1857;

15. Устав лесной 1876 года издания // СЗРИ. - Т.8 - Ч.І - Уставы: лесной, о казенных оброчных статьях, об управлении казенными имениями в Западных и Прибалтийских губерниях. - СПб., 1876.

16. Устав лесной 1905 г. // СЗРИ. - Т. 8. - Ч.1. - СПб., 1905 г.

17. Устав Лесной 1913 г. // СПб., 1913 (Типолитография Якорь).

18. Шелгунов Н. История русского лесного законодательства. - Санкт-Петербург. Типография Министерства гос. им-в, 1857. - 378 с.

19. Шуплецова Ю.И. Вещные права на природные ресурсы: публичные и частные интересы [Текст] / Ю.И. Шуплецова. - М.: ИД «Юриспруденция», 2007. - 160 c.

\section{References (transliteration):}

1. Kichigin N.V. Gorodskie lesa: rezhim // Zhurnal rossiyskogo prava. - 2011. - №6.

2. Narysheva N.G. Pravo sobstvennosti na zemli, zanyatye gorodskimi lesami // Imushchestvennye otnosheniya v Rossiyskoy Federatsii. - 2010. - №12.

3. Polyanskaya G.N. Pravo gosudarstvennoy sobstvennosti na lesa v SSSR. - M.: Gosudarstvennoe izdatel'stvo yuridicheskoy literatury, 1959. - $407 \mathrm{~s}$.

4. Shelgunov N. Istoriya russkogo lesnogo zakonodatel'stva. - Sankt-Peterburg. Tipografiya Ministerstva gos. im-v, 1857. - $378 \mathrm{~s}$.

5. Shupletsova Yu.I. Veshchnye prava na prirodnye resursy: publichnye i chastnye interesy [Tekst] / Yu.I. Shupletsova. - M.: ID «Yurisprudentsiya», 2007. - 160 s. 